\title{
Validity and Reliability of the DeMoulin Self-Concept Developmental Scale for the 36-72 Month Old Children
}

\author{
Rengin Zembat ${ }^{1}$, Nalan Kuru Turaşlıํㄹ Gülçin Güven ${ }^{3}$, Türker Sezer ${ }^{4}$, Ezgi Akşin ${ }^{5}$, Elif Yılmaz ${ }^{6}$, Dilan Bayındır ${ }^{7}$ \\ 1, 3, 5, 6,7 Atatürk Education Faculty, Marmara University, İstanbul, Turkey \\ ${ }^{2}$ Education Faculty, Uludağ University, Bursa, Turkey \\ ${ }^{4}$ Education Faculty, Abant Izzet Baysal University, Bolu, Turkey \\ Correspondence: Türker Sezer, Education Faculty, Abant Izzet Baysal University, Gölköy Campus, 14280, Bolu, Turkey
}

Received: October 20, 2015 Accepted: November 10, $2015 \quad$ Online Published: November21, 2015

doi:10.11114/jets.v4i2.1156 URL: http://dx.doi.org/10.11114/jets.v4i2.1156

\begin{abstract}
The aim of this study is to investigate the reliability and validity of the DeMoulin Self-Concept Developmental Scale for 36-72 month old children. In addition, it has been attempted to examine the effects of age and gender variables on the self-concept of children. The study is in survey method. The sample consists of 810 children who attend preschools in Istanbul, Turkey. Data collection tools used in the research are; the Demographic Form, the DeMoulin Self-Concept Developmental Scale for Children, the Social Competence and Behavior Evaluation Scale-30 and the Emotion Regulation Scale. The results of the item discrimination and criteria validity analyses support the validity of the scale. It could be said that the founded Cronbach's Alpha value of the total scale and subscales and the results of the split half method and test-retest method analyses indicate that the scale is a reliable measurement tool. In addition, it has been found that the age variable affected the self-concept scores, but the gender variable had no effect on it. The research findings are discussed within the framework of the related literature.
\end{abstract}

Keywords: Self-concept, preschool, validity, reliability, age, gender

\section{Introduction}

Self-concept as a general term that refers to "being able to deliberately define his own existence apart from the environment and from other people" (Huitt, 2011). This concept is also accepted as a person's perceptions, feelings, and impressions about him/herself (Plucker and Stocking, 2002; Marshall, 1989; Wall, 1986 all cited in Kapıkıran, 2004). Self-concept reflects all the experiences that we have encountered during the whole life and positive or negative values associated with them (DeMoulin, 2000).

Self-concept, which has been accepted as a person's self-interpretation, was one of the most interesting topics throughout the history of humanity. Self is a concept attracting very high interest from philosophers and thinkers first, then from historians and politicians, and from psychologists and educators in the last century. Today, the concept of self is considered as one of the most fundamental topics of humanity (Hattie, 2014).

The concept of self has many implications on the values, beliefs and attitudes of the individual, and on his whole life in terms of personal, physical and social aspects (Arnold and Boggs, 2011). The concept of self, which has such a wide impact range, therefore requires a multi-dimensional explanation (Sallay, 2000). James (1957) considered self as "the objective self and subjective self" (cited in Huitt, 2011); Rogers (1980) as, "actual self and ideal self" (cited in Bukato and Daehler, 1992); Lindenfield (1997), as "inner confidence and outer confidence" (cited in Özbey, 2004); DeMoulin (2000) as "self-efficacy and self-esteem".

The widely accepted view is that self-concept is not an innate property; it is a situation mostly occurs with the age and socio-physical surrounding. In the formation of self-concept, childhood is the crucial period (DeMoulin, 2000). The period starting with the birth of the child and continues until the age of one is accepted as the period where the sense of basic confidence is formed. Up to three year-old, the surrounding people's attitudes will be decisive on the child's self-concept. After three year-old, children continuously ask question and attempt to understand the events occurring around them. The reaction of their surrounding is the second cornerstone of their confidence development (Thompson, Barnsley and Battle, 2004). 
In the field of social sciences, the self-concept and the impacts of self-concept on the life of the individual, is an issue that researchers often are working on. The review of the studies conducted on this issue indicated that the self-concept in the childhood period is affected by the relations with the social surrounding formed by the family, friends and teacher (Pallini, Baiocco, Schneider, Madigan and Atkinson, 2014; Spilt, Lier, Leflot, Onghena and Colpin, 2014; Verschueren, Doumen and Buyse, 2012; Vervoort, Bosmans, Doumen, Minnis and Verschueren, 2014), if affects the child's life quality, academic success (Gullo, 2015, Määttä, Järvelä and Perry, 2015) and attitude towards school (Günalp, 2007; Kuru-Turaşl1, 2006). Even though long terms effects of self-concept on the life of the individual have been proven in many researches and it is a highly popular topic in the field of social sciences, the measurement of self-concept on the early ages is quite difficult. There are two main reasons for this difficulty. First, the awareness of self is just begun to emerge in this period. Second, many factors that should be addressed within the concept of self are nested. Moreover, illiteracy of the children, the influence of various factors (such as family, immediate surroundings and teacher) on self-concept, being a highly abstract issue, the difficulties of pre-school children's in defining the facts can be considered among the other factors complicating the measurement process (Kuru-Turaşl1, 2014).

The review of the literature revealed some instruments used in the measurement of children's self-concept. The most known and common of them are the Coopersmith Self Esteem Inventory -CSEI, developed in 1967 and the Piers-Harris Children's Self-Concept Scale, developed in 1984 (Öner, 2009). Both scales consist of the elements considered as having an impact on the child's self-concept (e.g. cognitive competence, physical skills, being popular, parental attitudes, moral values, personality traits, physical characteristics and emotional reactions) and a general conclusion is derived using all these aspects (Van den Bergh and Van Ranst, 1998). Apart from these, there are other measurements tools evaluating self-concept, for example the Preschool and Primary Self-Concept Scale, the Harter Self-Concept Scale (HSCS), the Perceived Competence Scale for Children and the Pictorial Scale of Perceived Competence and Social Acceptance for Young Children (Stager and Young, 1982 cited in Harter, 1985; Harter and Pike, 1984 cited in Cugmas, 2002). In addition to these, the DeMoulin Self-Concept Developmental Scale (DSCDS) is also used as a measurement tool that provides a systematic and comparative analysis of children's personal self-concept and making diagnosis (DeMoulin, 2000).

The DeMoulin Self-Concept Developmental Scale for 5-6 year-old children was adapted into Turkish by Kuru-Turaşlı (2006, 2014). The scale was prepared considering the characteristics of the children who cannot read and write, children are asked to reflect their reactions towards the statements read to them by coloring various facial expressions. However, the review of the above mentioned measurement tools adapted to Turkish revealed a shortcoming in measuring younger (3-4 year-old) children's self-concept. As mentioned above, most of the tools developed towards measuring self-concept either addresses elementary school level or children with special needs. Therefore, it is believed that our country needs a measurement tool used to assess self-concept of normally developed children of the younger age group. Also, this scale is choosen because it makes children active during the process and this keep children's attention. The child is asked to paint the facial expression that he/she believes best reflects his/her feelings about the item statement that the researcher read to her/him. Also, the duration of the application of the scale lasts for 20 minutes in average. So, it can be said that it does not take too much time for the evaluation of the concept. Furthermore, it is easy to apply. The child and administrator sit facing each other at a table and all required are question sheets and colored pencils. Starting from this need and these reasons, the purpose of this study is adapting the DeMoulin Self-Concept Developmental Scale, which has the potential of assessing self-concept development of normally developed 3-6 year-old children and testing the reliability and validity of the scale.

According to Harter $(1983,1985,1999)$, the self-concept of young children are very positive unrealisticly. This is because children have difficulties to distinguish between the actual and desired attirubes and incorporate socail comparisons. The results of Harter's research indicated that the perception of self-esteem of children about themselves increase by cognitive development and age. Many other studies' results support this finding (Bouffard, Markovits, Vezeau, Boisvert, \& Dumas, 1998; Eccles, 1993; Eccles, Wigfield, Harold, \& Blumenfeld, 1993; Wigfield, \& Eccles, 1992; Wigfield, Eccles, Yoon, Harold, Arbreton, Freedman-Doan, \& Blumenfeld, 1997). Because of this issue, it has been analysed the effect of the age variable on the self concept as a part of this study. Also, the effect of gender variable on self concept is seen as a topic of many other research (Bosacki, 2007; Eccles, Wigfield, Harold, \& Blumenfeld, 1993; Kling, Hyde, Showers, \& Buswell, 1999; Preckel, Goetz, Pekrun, \& Kleine, 2008; Wilgenbusch \& Merrell, 1999). However, DeMoulin (1999) stresses that self concept is not gender specific. So, this is one of the other questions of the research if the self-concept of 36-72 month children differ according to gender or not.

\section{Methodology}

\subsection{Research Design}

The study is designed as a quantitative research according to survey method. First, the validity-reliability of the DeMoulin Self-Concept Developmental Scale for 36-72 month-old children was checked and then children's self-concepts were 
analyzed according to age and gender.

\subsection{Participants}

Sample of the study consists of 810 children, selected by random cluster sampling method, from 11 different pre-school institutions, namely 4 independent kindergartens, 5 kindergartens of primary schools and 2 private kindergartens, located at the Anatolian site of Istanbul, Turkey (Kadıkoy, Atasehir, Uskudar, Maltepe), during academic years 2013-2014. 423 children are female (52.4\%) whereas 387 of them are male (47.6\%); 183 of the children are 36-48 month-old (22.6\%), 348 of them are 49-60 month-old (43\%), and 279 of them are 61-72 month-old (34.4\%).

\subsection{Data Collection Tools}

Data collection tools used in the research were; the Demographic Form, the DeMoulin Self-Concept Developmental Scale for Children, whose validity-reliability was checked within the study, the Social Competence and Behavior Evaluation Scale-30 and the Emotion Regulation Scale, which were used to check the criteria validity of the scale.

2.3.1 Demographic Form: Demographic Information (Age and Gender) of the Children Participating in the Study Were Obtained through this Form Developed by the Researchers

2.3.2 DeMoulin Self-Concept Developmental Scale for Children: "DeMoulin Self-Concept Developmental Scale for Children" is a measuring tool that provides a systematic and comparative analysis of children's personal self-concept and making diagnosis, developed by Dr. Donald DeMoulin in 1995-1998. The scale consists of two sub-dimensions and a total of 30 items, namely "Self-Esteem" (15 items) and "Self-Efficacy" (15 items). In the adaptation of Kuru-Turaşl1 $(2006,2014)$ for 6 year-old children, one item of "Self-Esteem" dimension has been removed. The assessment form was evaluated by giving 3 points to each smiley face, 2 points to each expressionless face and 1 point to each unhappy face.

2.3.3 Social Competence and Behavior Evaluation Scale-30: The Social Competence and Behavior Evaluation Scale-30 (SCBE-30) was developed by LaFreniere and Dumas (1996) and its adaptation to Turkish was performed by Çorapç1, Aksan, Arslan-Yalçın and Yağmurlu (2010). This 6-points likert scale consists of 30 items evaluating the symptoms of children's problem and the quantity of the social skills grouped under three sub-scales, namely "Social Competence", "Anger-Aggression" and "Anxiety-Withdrawal". "Social Competence" subscale measures children's positive features, such as the cooperation and seeking solutions to conflicts when they are within the peer group. "Anger-Aggression" subscale assesses the symptoms of externalizing problems, such as defiance to the adults and acting discordantly and aggressively in peer relationships, whereas "Anxiety Withdrawal" assesses the sad, depressive moods of children and the symptoms of internalizing, such as showing timidity in the group. Cronbach's Alpha internal consistency coefficients of these subscales were found to be $.88, .87$ and .84 respectively. They have been evaluated by children's teachers.

2.3.4 Emotion Regulation Scale: Emotion Regulation Scale was developed by Shields and Cicchetti (1997) and the Turkish adaptation was performed by Batum and Yağmurlu (2007). This 4-points likert scale consists of 24 items evaluating pre-school and school-age children's emotional reactiveness and the regulation and expression of their emotions of according to the environment, grouped under two sub-dimensions, namely "Emotion Regulation" and "Lability/Negativity". Cronbach's Alpha internal consistency coefficients of the scale were found to be .73 for Emotion Regulation subscale and .75 for Lability/Negativity subscale. They have been evaluated by children's teachers.

\subsection{Data Collection Procedure}

The data of the research has been collected by applying the scale to the participating children personally by the researchers. Before the application, researchers have met the children and have spent a day with them, have participated in the activities at the classroom. Then, the researcher applied the scale personally in a classroom or room provided by the school administration.

\subsection{Data Analysis}

The data obtained through the DeMoulin Self-Concept Developmental Scale for Children have been analyzed using appropriate statistics software. The following statistical procedures have been run to check the validity and reliability of the scale.

Validity procedures:

-Criterion validity (Pearson product-moment correlation coefficient)

Reliability procedures:

-Item Analysis (Pearson product-moment correlation coefficient, independent group t-test and item differentiation indexes)

-Continuity Coefficient (test-retest and split-half test) 
-Internal Consistency Coefficients (Cronbach $\alpha$ )

In addition descriptive statistics (percentage, frequency, mean and standard deviation) and difference tests (t-test, analysis of variance / ANOVA) were used while analyzing children's self-concept according to age and gender. In the analysis, statistical significant level was taken as 0.05 .

\section{Findings}

This part includes the findings about the validity and reliability of the DeMoulin Self-Concept Developmental Scale for Children along with the findings about the differentiation of children's self-concept according to age and gender.

Table 1. Item-Total Statistics (a)

\begin{tabular}{|c|c|c|c|c|}
\hline Item No & $\begin{array}{c}\text { Scale Mean if Item } \\
\text { Deleted }\end{array}$ & $\begin{array}{c}\text { Scale Variance if Item } \\
\text { Deleted }\end{array}$ & $\begin{array}{c}\text { Corrected Item Total } \\
\text { Correlation }\end{array}$ & $\begin{array}{l}\text { Cronbach's Alpha if } \\
\text { Item Deleted }\end{array}$ \\
\hline I1 & 70.960 & 55.961 & .212 & .806 \\
\hline I2 & 71.259 & 53.171 & .396 & .798 \\
\hline I3 & 71.263 & 53.393 & .373 & .799 \\
\hline I4 & 71.513 & 53.892 & .285 & .804 \\
\hline I5 & 71.025 & 55.081 & .275 & .803 \\
\hline I6 & 71.085 & 54.043 & .381 & .799 \\
\hline I7 & 71.138 & 53.420 & .405 & .798 \\
\hline I8 & 71.059 & 54.058 & .381 & .799 \\
\hline I9 & 71.164 & 53.492 & .394 & .798 \\
\hline $\mathrm{I} 10$ & 71.161 & 54.514 & .282 & .803 \\
\hline I11 & 71.123 & 53.579 & .415 & .798 \\
\hline $\mathrm{I} 12$ & 72.202 & 55.336 & .167 & .810 \\
\hline I13 & 71.144 & 54.722 & .274 & .804 \\
\hline I14 & 71.149 & 53.670 & .398 & .798 \\
\hline I15 & 72.437 & 56.817 & .089 & .810 \\
\hline I16 & 70.900 & 56.416 & .200 & .806 \\
\hline I17 & 70.956 & 54.795 & .389 & .800 \\
\hline $\mathrm{I} 18$ & 71.016 & 53.952 & .435 & .798 \\
\hline I19 & 70.998 & 54.251 & .396 & .799 \\
\hline I 20 & 71.118 & 54.737 & .267 & .804 \\
\hline I 21 & 71.627 & 54.457 & .197 & .810 \\
\hline I 22 & 70.996 & 56.342 & .162 & .807 \\
\hline I 23 & 71.093 & 54.362 & .327 & .801 \\
\hline I 24 & 71.102 & 53.190 & .459 & .796 \\
\hline I 25 & 70.933 & 55.224 & .326 & .802 \\
\hline I 26 & 71.109 & 53.735 & .409 & .798 \\
\hline I 27 & 71.172 & 53.399 & .382 & .799 \\
\hline I 28 & 71.109 & 53.967 & .363 & .800 \\
\hline I29 & 71.021 & 54.750 & .332 & .801 \\
\hline
\end{tabular}

Table 1 shows the correlation of each item, included in the DeMoulin Self-Concept Developmental Scale for Children with the rest. According to item-total correlation values, it has been found that the lowest value is .089 (Item15), whereas the highest value is .459 (Item24) and it has been concluded that the reliability of the scale would increase if Item 15 is removed from the scale.

The analysis of the changes on the mean of the scale in case of removing the item showed that the lowest value of the mean became 70.90 (Item16), whereas the highest value became 72.43 (Item15). According to this finding the mean of the scale decreases if Item 16 is removed from the scale whereas it increases if Item15 is removed. Moreover, the analysis of the change on the variances in case of removing the item showed that lowest value became 53.17 (Item2), whereas the highest value became 56.81 (Item15). According to this finding scale's variance decreases if Item2 is removed from the scale, whereas it increases if Item 15 is removed. In addition to these findings, the analysis of the change on the reliability coefficient of the scale if the item is removed showed that lowest value became .796 (Item24), whereas the highest value became .810 (Item12, Item15, Item21) and the overall reliability coefficient of the scale (Cronbach's Alpha Value) was .807.

One item (Item15), whose contribution to the scale was found to be low, was removed from the scale and Item-Total Analysis was repeated. The results are displayed in Table 2. 
Table 2. Item-Total Statistics (b)

\begin{tabular}{ccccc}
\hline Item No & $\begin{array}{c}\text { Scale Mean if Item } \\
\text { Deleted }\end{array}$ & $\begin{array}{c}\text { Scale Variance if Item } \\
\text { Deleted }\end{array}$ & $\begin{array}{c}\text { Corrected Item Total } \\
\text { Correlation }\end{array}$ & $\begin{array}{c}\text { Cronbach's Alpha if } \\
\text { Item Deleted }\end{array}$ \\
\hline I1 & 69.653 & 54.803 & .211 & .809 \\
I2 & 69.951 & 51.994 & .400 & .801 \\
I3 & 69.955 & 52.265 & .373 & .803 \\
I4 & 70.206 & 52.863 & .275 & .808 \\
I5 & 69.718 & 53.889 & .279 & .807 \\
I6 & 69.777 & 52.888 & .382 & .801 \\
I7 & 69.830 & 52.249 & .409 & .803 \\
I8 & 69.751 & 52.919 & .381 & .802 \\
I9 & 69.856 & 52.338 & .396 & .807 \\
I10 & 69.854 & 53.398 & .279 & .814 \\
I11 & 69.816 & 52.422 & .417 & .807 \\
I12 & 70.895 & 54.504 & .139 & .802 \\
I13 & 69.837 & 53.509 & .280 & .809 \\
I14 & 69.842 & 52.499 & .401 & .803 \\
I16 & 69.592 & 55.159 & .214 & .801 \\
I17 & 69.649 & 53.548 & .402 & .802 \\
I18 & 69.708 & 52.803 & .436 & .807 \\
I19 & 69.691 & 53.032 & .405 & .814 \\
I20 & 69.811 & 53.590 & .267 & .810 \\
I21 & 70.319 & 53.444 & .186 & .804 \\
I22 & 69.688 & 55.100 & .171 & .799 \\
I23 & 69.786 & 53.179 & .330 & .805 \\
I24 & 69.795 & 52.042 & .461 & .801 \\
I25 & 69.625 & 53.987 & .337 & .802 \\
I26 & 69.802 & 52.577 & .411 & .803 \\
I27 & 69.865 & 52.240 & .384 & .805 \\
I28 & 69.802 & 52.831 & .363 & .331 \\
I29 & 69.713 & 53.604 & 509 \\
\hline
\end{tabular}

Table 2 shows the correlation of each item covered in the DeMoulin Self-Concept Developmental Scale for Children with the other items. According to item-total correlation values, it has been found that the lowest value is .139, whereas the highest value is .461 .

The analysis of the change on the mean of the scale in case of removing the item showed that the lowest value became 69.59, whereas the highest value became 70.89. Moreover, the analysis of the change on the variances in case of removing the item showed that lowest value became 51.99, whereas the highest value became 55.10. In addition to these findings, the analysis of the change on the reliability coefficient of the scale in case of removing the item showed that lowest value became .799 by removing Item24, whereas the highest value became.814 by removing Item12 and Item21. The total reliability coefficient of the scale (Cronbach's Alpha Value) was calculated as .810.

Means and standard deviations of the DeMoulin Self-Concept Developmental Scale for Children's item are given in Table 3.

Table 3. Means and Standard Deviations of the Items

\begin{tabular}{cccc}
\hline Item No & $\overline{\mathrm{X}}$ & $\mathrm{Sd}$ & $\mathrm{N}$ \\
\hline $\mathrm{I} 1$ & 2.784 & .548 & 810 \\
$\mathrm{I} 2$ & 2.485 & .741 & 810 \\
$\mathrm{I} 3$ & 2.481 & .742 & 810 \\
$\mathrm{I} 4$ & 2.230 & .819 & 810 \\
$\mathrm{I} 5$ & 2.718 & .620 & 810 \\
I6 & 2.659 & .634 & 810 \\
I7 & 2.606 & .691 & 810 \\
I8 & 2.685 & .631 & 810 \\
I9 & 2.580 & .697 & 810 \\
I10 & 2.582 & .714 & 810 \\
I11 & 2.621 & .656 & 810 \\
I12 & 1.542 & .808 & 810 \\
I13 & 2.600 & .691 & 810 \\
I14 & 2.595 & .666 & 810 \\
I16 & 2.844 & .456 & 810 \\
I17 & 2.787 & .511 & 810 \\
I18 & 2.728 & .580 & 810 \\
I19 & 2.745 & .583 & 810 \\
I20 & 2.625 & .701 & \\
\hline
\end{tabular}


Table 3 continued

\begin{tabular}{cccc}
\hline I21 & 2.117 & .924 & 810 \\
I22 & 2.748 & .554 & 810 \\
I23 & 2.650 & .663 & 810 \\
I24 & 2.642 & .654 & 810 \\
I25 & 2.811 & .516 & 810 \\
I26 & 2.634 & .642 & 810 \\
I27 & 2.571 & .729 & 810 \\
I28 & 2.634 & .670 & 810 \\
I29 & 2.723 & .590 & 810 \\
\hline$\sum \bar{X}$ & & 72.437 & \\
$\sum \mathrm{S}^{2}$ & & 56.817 & \\
\hline
\end{tabular}

Table 3 shows that the item within the DeMoulin Self-Concept Developmental Scale for Children with the highest mean is Item 26 with a value of 2.844 , whereas the item with the lowest mean is Item12 with 1.542 . Regarding the standard deviations of the items, the highest standard deviation is .924 and it belongs to Item21. On the other hand Item16 has the lowest standard deviation, with .456. In addition to these findings, the total mean of the scale was found to be 72.437, the variance is 56.817 and standard deviation is 7.537 .

Means, minimum, maximum, ranges and variances of the items of the DeMoulin Self-Concept Developmental Scale for Children were analyzed and are presented in Table 4.

Table 4. Means, Minimum, Maximum, Ranges and Variances of the Items

\begin{tabular}{cccccccc}
\hline & $\overline{\mathrm{x}}$ & Min. & Max. & Range & Max. / Min. & Variance & $\begin{array}{c}\text { Number of } \\
\text { Items }\end{array}$ \\
\hline Item Means & 2.587 & 1.542 & 2.844 & 1.302 & 1.845 & .066 & 28 \\
Item Variances & .444 & .208 & .855 & .647 & 4.108 & .019 & 28 \\
\hline
\end{tabular}

Table 4 shows that the mean of the DeMoulin Self-Concept Developmental Scale for Children is 2.587, minimum value of the items is 1.542 , maximum value of the items is 2.844 , its range is 1.302 and its variance is .66. In addition the mean of items' variance is .444 , the minimum value of the items' variance is .208 , the maximum value of the variance is .855 , its range is .647 and its variance is .019 .

The additivity of the DeMoulin Self-Concept Developmental Scale for Children was checked via ANOVA with Tukey's Test for Non-additivity and the results are displayed in Table 5.

Table 5. ANOVA with Tukey's Test for Non-additivity

\begin{tabular}{lcccccc}
\hline & & Sum of & \multirow{2}{*}{ df } & Mean & \multirow{2}{*}{$\mathrm{F}$} & $\mathrm{p}$ \\
\hline Between Groups & Squares & Squares & & & \\
Within Groups & Difference between items & 1641.617 & 809 & 2.029 & & \\
& Non-additivity & 1452.885 & 2 & 53.811 & 139.799 & $.000 *$ \\
& 1.571 & 1 & 1.571 & 4.081 & .053 \\
\hline
\end{tabular}
$*_{p} \overline{r .05}$

According to Table 5, the items constituting the DeMoulin Self-Concept Developmental Scale for Children were found to be homogeneous and correlated $(F=139.799, \mathrm{p}<.05)$. In addition the scale is found to be additive $(\mathrm{F}=4.081, \mathrm{p}>.05)$.

The results of split-half test of the DeMoulin Self-Concept Developmental Scale for Children are displayed in table 6.

Table 6. Split-Half Test

\begin{tabular}{|c|c|c|c|c|c|}
\hline Split-Half Test & & $\begin{array}{c}\text { Cronbach's } \\
\text { Alpha }\end{array}$ & $\begin{array}{c}\text { Pearson } \\
\text { Correlations } \\
\end{array}$ & $\begin{array}{c}\text { Spearman-Brown } \\
\text { Coefficient }\end{array}$ & $\begin{array}{c}\text { Guttman Split-Half } \\
\text { Coefficient }\end{array}$ \\
\hline \multirow[t]{2}{*}{ First Half of the Scale } & Value & .683 & & & \\
\hline & $\begin{array}{l}\text { Number } \\
\text { of Items }\end{array}$ & 14(a) & & & \\
\hline \multirow[t]{2}{*}{ Second Half of the Scale } & Value & .685 & .673 & .805 & .803 \\
\hline & $\begin{array}{l}\text { Number } \\
\text { of Items }\end{array}$ & 14(b) & & & \\
\hline Total Number of Items & & 28 & & & \\
\hline
\end{tabular}

According to Table 6, there is a significant relationship between the two half of the DeMoulin Self-Concept Developmental Scale for Children; Pearson correlation coefficient was calculated as .673, Spearman-Brown coefficient as .805 and Guttman Split-Half coefficient as .803. Moreover, Cronbach's Alpha value was found to be .683 for the first half of the scale, whereas it was. 685 for the second half.

Gutmann Lambda ( $\mathrm{Li}$ ) coefficients of the DeMoulin Self-Concept Developmental Scale for Children were analyzed and the results are presented in Table 7. 
Table 7. Reliability Coefficients According to Guttman Lambda (Li) Method

\begin{tabular}{lcc}
\hline & Guttman Lambda (Li) Coefficients & \\
\hline & 1 & .781 \\
& 2 & .814 \\
& 3 & .810 \\
Number of Items & 4 & .803 \\
& 5 & .797 \\
& 6 & .781 \\
\hline
\end{tabular}

Table 7 shows that reliability coefficients of the DeMoulin Self-Concept Developmental Scale for Children According to Guttman Lambda (Li) method vary between .781 and .814 .

Item differentiation values of the DeMoulin Self-Concept Developmental Scale for Children were analyzed and the results are shown in Table 8.

Table 8. Item Discriminations

\begin{tabular}{|c|c|c|c|c|c|c|c|c|}
\hline Items & \multicolumn{2}{|c|}{ Group } & $\mathrm{N}$ & $\overline{\mathrm{x}}$ & $\mathrm{Sd}$ & $\mathrm{t}$ & df & $p$ \\
\hline \multirow[t]{2}{*}{ I1 } & Lower & $27 \%$ & 219 & 2.21 & .80 & \multirow{2}{*}{-14.570} & \multirow{2}{*}{436} & \multirow{2}{*}{$.000 *$} \\
\hline & Upper & $27 \%$ & 219 & 3.00 & .00 & & & \\
\hline \multirow[t]{2}{*}{ I2 } & Lower & $27 \%$ & 219 & 1.44 & .49 & \multirow{2}{*}{-46.100} & \multirow{2}{*}{436} & \multirow{2}{*}{$.000 *$} \\
\hline & Upper & $27 \%$ & 219 & 3.00 & .00 & & & \\
\hline \multirow[t]{2}{*}{ I3 } & Lower & $27 \%$ & 219 & 1.77 & .42 & \multirow{2}{*}{-43.207} & \multirow{2}{*}{436} & \multirow{2}{*}{$.000 *$} \\
\hline & Upper & $27 \%$ & 219 & 3.00 & .00 & & & \\
\hline \multirow[t]{2}{*}{ I4 } & Lower & $27 \%$ & 219 & 1.08 & .28 & \multirow{2}{*}{-100.358} & \multirow{2}{*}{436} & \multirow{2}{*}{$.000^{*}$} \\
\hline & Upper & $27 \%$ & 219 & 3.00 & .00 & & & \\
\hline \multirow[t]{2}{*}{ I5 } & Lower & $27 \%$ & 219 & 1.95 & .79 & \multirow{2}{*}{-19.320} & \multirow{2}{*}{436} & $000 *$ \\
\hline & Upper & $27 \%$ & 219 & 3.00 & .00 & & & $.000^{2}$ \\
\hline I6 & Lower & $27 \%$ & 219 & 1.73 & .57 & & & $000 *$ \\
\hline & Upper & $27 \%$ & 219 & 3.00 & .00 & -32.410 & 430 & $.000^{2}$ \\
\hline I7 & Lower & $27 \%$ & 219 & 1.55 & .49 & 42880 & 436 & $0 \cap 0 *$ \\
\hline & Upper & $27 \%$ & 219 & 3.00 & .00 & -42.009 & 450 & .000 \\
\hline I8 & Lower & $27 \%$ & 219 & 1.83 & .69 & & & \\
\hline & Upper & $27 \%$ & 219 & 3.00 & .00 & -24.702 & 436 & $.000^{*}$ \\
\hline I9 & Lower & $27 \%$ & 219 & 1.55 & .49 & 42087 & 436 & 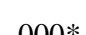 \\
\hline & Upper & $27 \%$ & 219 & 3.00 & .00 & -42.982 & 436 & $.000^{x}$ \\
\hline I10 & Lower & $27 \%$ & 219 & 1.50 & .50 & & & \\
\hline & Upper & $27 \%$ & 219 & 3.00 & .00 & -44.096 & 436 & $.000^{*}$ \\
\hline I11 & Lower & $27 \%$ & 219 & 1.63 & .48 & & & \\
\hline & Upper & $27 \%$ & 219 & 3.00 & .00 & -41.838 & 436 & $.000^{*}$ \\
\hline I12 & Lower & $27 \%$ & 219 & 1.00 & .00 & & 436 & $000 *$ \\
\hline & Upper & $27 \%$ & 219 & 2.74 & .43 & -59.542 & 430 & $.000^{*}$ \\
\hline I13 & Lower & $27 \%$ & 219 & 1.56 & .49 & & & $000 *$ \\
\hline & Upper & $27 \%$ & 219 & 3.00 & .00 & -42.801 & 436 & $.000^{*}$ \\
\hline I14 & Lower & $27 \%$ & 219 & 1.62 & .48 & -41 930 & 436 & $000 *$ \\
\hline & Upper & $27 \%$ & 219 & 3.00 & .00 & -41.930 & 430 & $.000^{x}$ \\
\hline I16 & Lower & $27 \%$ & 219 & 2.42 & .72 & 11607 & 436 & $0 \cap \cap *$ \\
\hline & Upper & $27 \%$ & 219 & 3.00 & .00 & 11.09ו & 450 & .000 \\
\hline I17 & Lower & $27 \%$ & 219 & 2.21 & .71 & 16150 & 126 & $\cap \cap \cap *$ \\
\hline & Upper & $27 \%$ & 219 & 3.00 & .00 & -16.150 & 436 & $.000^{2}$ \\
\hline I18 & Lower & $27 \%$ & 219 & 1.99 & .71 & & & \\
\hline & Upper & $27 \%$ & 219 & 3.00 & .00 & -20.834 & 436 & $.000^{*}$ \\
\hline I19 & Lower & $27 \%$ & 219 & 2.05 & .78 & -17740 & 436 & $0 \cap 0 *$ \\
\hline & Upper & $27 \%$ & 219 & 3.00 & .00 & $-1 \% .140$ & 450 & .000 \\
\hline I20 & Lower & $27 \%$ & 219 & 1.61 & .64 & 31555 & 436 & $000 *$ \\
\hline & Upper & $27 \%$ & 219 & 3.00 & .00 & -31.555 & 436 & $.000^{2}$ \\
\hline I21 & Lower & $27 \%$ & 219 & 1.00 & .09 & -45190 & 436 & $000 *$ \\
\hline & Upper & $27 \%$ & 219 & 2.55 & .49 & -45.190 & 450 & $.000^{x}$ \\
\hline $\mathrm{I} 22$ & Lower & $27 \%$ & 219 & 2.06 & .71 & -19.409 & 436 & $.000 *$ \\
\hline & Upper & $27 \%$ & 219 & 3.00 & .00 & & & \\
\hline $\mathrm{I} 23$ & Lower & $27 \%$ & 219 & 1.70 & .64 & -29880 & 436 & $000 *$ \\
\hline & Upper & $27 \%$ & 219 & 3.00 & .00 & -29.880 & 450 & $.000^{x}$ \\
\hline I24 & Lower & $27 \%$ & 219 & 1.67 & .55 & -35620 & 436 & $000 *$ \\
\hline & Upper & $27 \%$ & 219 & 3.00 & .00 & -35.620 & 436 & $.000^{\circ}$ \\
\hline I 25 & Lower & $27 \%$ & 219 & 2.30 & .79 & -12989 & 436 & $000 *$ \\
\hline & Upper & $27 \%$ & 219 & 3.00 & .00 & -12.909 & 450 & .000 \\
\hline I26 & Lower & $27 \%$ & 219 & 1.66 & .47 & -41.761 & 436 & $.000 *$ \\
\hline
\end{tabular}


Table 8 continued

\begin{tabular}{lllllllll}
\hline \multirow{2}{*}{27} & Upper & $27 \%$ & 219 & 3.00 & .00 & & & \\
& Lower & $27 \%$ & 219 & 1.47 & .50 & -45.251 & 436 & $.000^{*}$ \\
$\mathrm{I} 28$ & Upper & $27 \%$ & 219 & 3.00 & .00 & & & \\
& Lower & $27 \%$ & 219 & 1.64 & .57 & -34.822 & 436 & $.000^{*}$ \\
$\mathrm{I} 29$ & Upper & $27 \%$ & 219 & 3.00 & .00 & .72 & & \\
& Lower & $27 \%$ & 219 & 1.97 & .20 .851 & 436 & $.000^{*}$ \\
\hline
\end{tabular}

$$
* p<.001
$$

In order to analyze the discriminations level of the items included in the DeMoulin Self-Concept Developmental Scale for Children, independent t-test were performed between the upper $27 \%$ and lower $27 \%$ scores of each item and it has been found that there are significant differences for all items between groups $(\mathrm{p}<.05)$.

Table 9. Test-Retest Coefficients

\begin{tabular}{|c|c|c|c|c|}
\hline & & Pearson & Kendall's tau-b & Spearman's rho \\
\hline & & Retest & Retest & Retest \\
\hline \multirow{3}{*}{ Self-Esteem } & $\mathrm{r}$ & .595 & .433 & .562 \\
\hline & $\mathrm{p}$ & $.000^{*}$ & $.001 *$ & $.000 *$ \\
\hline & $\mathrm{n}$ & 36 & 36 & 36 \\
\hline \multirow{3}{*}{ Self-Efficacy } & $\mathrm{r}$ & .606 & .532 & .658 \\
\hline & $\mathrm{p}$ & $.000 *$ & $.000 *$ & $.000 *$ \\
\hline & $\mathrm{n}$ & 36 & 36 & 36 \\
\hline \multirow{3}{*}{$\begin{array}{l}\text { Self Concept Total } \\
\text { Score }\end{array}$} & $\mathrm{r}$ & .644 & .400 & .546 \\
\hline & $\mathrm{p}$ & $.000 *$ & $.001 *$ & $.001 *$ \\
\hline & $\mathrm{n}$ & 36 & 36 & 36 \\
\hline
\end{tabular}

$$
* p<.05
$$

According to Table 9, there is a significant relationship between test-retest results of the DeMoulin Self-Concept Developmental Scale for Children $(\mathrm{p}<.05)$. For self-esteem sub-dimension, Pearson correlation coefficient was calculated as .595, Kendall's tau-b coefficient as .433 and Spearman's rho coefficient as .562; for self-efficacy sub-dimension, Pearson correlation coefficient was calculated as .606, Kendall's tau-b coefficient as .532 and Spearman's rho coefficient as .658; whereas for the overall self-concept scores, Pearson correlation coefficient was calculated as .644, Kendall's tau-b coefficient as .400 and Spearman's rho coefficient as .546.

\begin{tabular}{|c|c|c|c|c|c|c|}
\hline & & \multicolumn{3}{|c|}{$\begin{array}{l}\text { Social Competence and Behavior Evaluation } \\
\text { Scale-30 }\end{array}$} & \multicolumn{2}{|c|}{ Emotion Regulation Scale } \\
\hline \multicolumn{2}{|l|}{$\begin{array}{l}\text { DeMoulin Self-Concept } \\
\text { Developmental Scale }\end{array}$} & $\begin{array}{c}\text { Social } \\
\text { Competence }\end{array}$ & $\begin{array}{c}\text { Anger- } \\
\text { Aggression }\end{array}$ & $\begin{array}{c}\text { Anxiety- } \\
\text { Introversion }\end{array}$ & $\begin{array}{c}\text { Emotion } \\
\text { Regulation }\end{array}$ & $\begin{array}{l}\text { Variability- } \\
\text { Negation }\end{array}$ \\
\hline \multirow{3}{*}{ Self-Esteem } & $\mathrm{r}$ & .383 & -.388 & -.120 & .299 & -.110 \\
\hline & $\mathrm{p}$ & $.000 *$ & $.000 *$ & .277 & $.006^{*}$ & .318 \\
\hline & $\mathrm{n}$ & 84 & 84 & 84 & 84 & 84 \\
\hline \multirow{3}{*}{ Self-Efficacy } & $\mathrm{r}$ & .367 & -.464 & -.205 & .360 & -.101 \\
\hline & $\mathrm{p}$ & $.001 *$ & $.000 *$ & .062 & $.001 *$ & .362 \\
\hline & $\mathrm{n}$ & 84 & 84 & 84 & 84 & 84 \\
\hline \multirow{3}{*}{ Self Concept Total Score } & $\mathrm{r}$ & .397 & -.447 & -.168 & .346 & -.112 \\
\hline & $\mathrm{p}$ & $.000 *$ & $.000 *$ & .127 & $.001 *$ & .311 \\
\hline & $\mathrm{n}$ & 84 & 84 & 84 & 84 & 84 \\
\hline
\end{tabular}

Table 10. Criterion validity results

The analysis of Table 10 showed that there is a positive and significant relationship between "Self-Esteem" subscale of the "DeMoulin Self-Concept Developmental Scale for Children" and "Social Competence" subscale of "Social Competence and Behavior Evaluation Scale-30" $(\mathrm{r}=.383, \mathrm{p}<.05)$, whereas there is a negative significant relationship between "Self-Esteem" and "Anger-Aggression" subscales $(\mathrm{r}=-, 388, \mathrm{p}<.05)$. Unlike these findings, there is not a significant relationship between "Self-Esteem" and "Anxiety withdrawal" subscales (r=-.120, $\mathrm{p}>.05)$.

Regarding the relations between "Self- Efficacy" subscale of the "DeMoulin Self-Concept Developmental Scale for Children" and the "Social Competence and Behavior Evaluation Scale-30", there is a positive and significant relationship between "Self- Efficacy" and "Social Competence" subscales $(r=.367, p<.05)$ whereas there is a negative significant relationship between "Self- Efficacy" and "Anger-Aggression" subscales ( $\mathrm{r}=-, 464, \mathrm{p}<.05)$. Unlike these findings, there is not a significant relationship between "Self- Efficacy" and "Anxiety withdrawal" sub-dimensions $(\mathrm{r}=-.205, \mathrm{p}>.05)$.

It has been found that the overall score of the "DeMoulin Self-Concept Developmental Scale for Children" has a 
positive and significant relationship with "Social Competence" subscale of the "Social Competence and Behavior Evaluation Scale-30" ( $\mathrm{r}=.397, \mathrm{p}<.05)$, whereas it has a negative significant relationship with "Anger-Aggression" subscale $(\mathrm{r}=-, 447, \mathrm{p}<.05)$. Unlike these findings, there is not a significant relationship between the total score of Self-Concept and Anxiety Withdrawal subscales ( $\mathrm{r}=-.168$, $\mathrm{p}>.05$ ).

It has been found that there is a positive significant relationship between "Self-Esteem" sub-dimension of "DeMoulin Self-Concept Developmental Scale for Children" and "Emotion Regulation" subscale of "Emotion Regulation Scale" $(\mathrm{r}=.299, \mathrm{p}<$.05). Unlike this finding, the relationship between "Self-Esteem" and "Variability-Negation" sub-dimensions is not significant $(\mathrm{r}=-.110, \mathrm{p}>.05)$.

It has been found that there is a positive significant relationship between "Self- Efficacy" subscale of the "DeMoulin Self-Concept Developmental Scale for Children" and "Emotion Regulation" subscale of "Emotion Regulation Scale" $(\mathrm{r}=.360, \mathrm{p}<.05)$. Unlike this finding, the relationship between "Self- Efficacy" and "Lability/Negativity" subscales is not significant ( $\mathrm{r}=-.101, \mathrm{p}>.05)$.

It has been found that there is a positive significant relationship between overall score of the "DeMoulin Self-Concept Developmental Scale for Children" and "Emotion Regulation" subscale of "Emotion Regulation Scale" (r=.346, $\mathrm{p}<.05)$. Unlike this finding, the relationship between overall score and "Lability/Negativity" subscale is not significant $(\mathrm{r}=-.112$, p>.05).

Table 11. Means and Standard Deviations of Children's Self-Concept Average Scores According to Age

\begin{tabular}{lcccc}
\hline Subscales & Age & $\mathrm{N}$ & $\overline{\mathrm{x}}$ & $\mathrm{Sd}$ \\
\hline \multirow{4}{*}{ Self-Esteem } & $36-48$ month-old & 183 & 34.45 & 4.67 \\
& $49-60$ month-old & 348 & 35.52 & 4.39 \\
& 61-72 month-old & 279 & 35.20 & 3.83 \\
& Total & 810 & 35.17 & 4.29 \\
\hline \multirow{3}{*}{ Self- Efficacy } & $36-48$ month-old & 183 & 36.25 & 4.63 \\
& $49-60$ month-old & 348 & 37.57 & 3.75 \\
& 61-72 month-old & 279 & 37.53 & 3.58 \\
Total Score & Total & 810 & 37.26 & 3.94 \\
& 36-48 month-old & 183 & 70.71 & 8.59 \\
& $49-60$ month-old & 348 & 73.09 & 7.40 \\
& $61-72$ month-old & 279 & 72.74 & 6.77 \\
\hline
\end{tabular}

As can be seen in Table 11, the average "Self-Esteem" scores of the children are: 34.45 for 36-48 month-old children, 35.52 for 49-60 month-old children and 35.20 for 61-72 month-old children. "Self- Efficacy" sub-dimension scores of the children are: 36.25 for 36-48 month-old children, 37.57 for 49-60 month-old children and 37.53 for 61-72 month-old children. The total scores are: 70.71 for 36-48 month-old children, 73.09 for 49-60 month-old children and 72.74 for 61-72 month-old children.

Table 12. ANOVA Test Results of Children's Self-Concept Average Scores According to Age

\begin{tabular}{|c|c|c|c|c|c|c|}
\hline Subscales & $\begin{array}{c}\text { Source of the } \\
\text { Variance }\end{array}$ & Sum of Squares & df & Mean Squares & $\mathrm{F}$ & $p$ \\
\hline \multirow{3}{*}{ Self-Esteem } & Between Groups & 135.490 & 2 & 67.745 & 3.703 & $.025^{*}$ \\
\hline & Within Group & 14763.657 & 807 & 18.294 & & \\
\hline & Total & 14899.147 & 809 & & & \\
\hline \multirow{3}{*}{ Self- Efficacy } & Between Groups & 240.743 & 2 & 120.372 & 7.853 & $.000 *$ \\
\hline & Within Group & 12369.189 & 807 & 15.327 & & \\
\hline & Total & 12609.932 & 809 & & & \\
\hline \multirow{3}{*}{ Total Score } & Between Groups & 719.967 & 2 & 359.984 & 6.421 & $.002 *$ \\
\hline & Within Group & 45245.322 & 807 & 56.066 & & \\
\hline & Total & 45965.289 & 809 & & & \\
\hline
\end{tabular}

According to Table 12, it has been found that there are significant differences between "Self-Esteem" $(\mathrm{F}=3.703)$ and Self- Efficacy ( $\mathrm{F}=7.853)$ subscales and total scores $(\mathrm{F}=6.421)$ of the "DeMoulin Self-Concept Developmental Scale for Children" according to age ( $\mathrm{p}<.05)$. In order to determine the groups between which this differences occurred Post hoc multiple comparison analysis were performed and the distribution of the data was checked through Levene statistics. It has been found that the data were not homogenously distributes $(\mathrm{p}<.05)$, the results of Tamhane's T2 Test are shown in Table 13. 
Table 13. Tamhane's T2 Test Results of Children's Self-Concept Average Scores According to Age

\begin{tabular}{|c|c|c|c|c|}
\hline Subscales & (I) Age & $(\mathrm{J})$ Age & Means Difference (I-J) & $\mathrm{p}$ \\
\hline \multirow{6}{*}{ Self-Esteem } & \multirow{2}{*}{ 36-48 month-old } & 49-60 month-old & -1.06110 & $.034 *$ \\
\hline & & $61-72$ month-old & -.74528 & .204 \\
\hline & \multirow{2}{*}{ 49-60 month-old } & 36-48 month-old & 1.06110 & $.034 *$ \\
\hline & & $61-72$ month-old & .31581 & .709 \\
\hline & \multirow{2}{*}{$61-72$ month-old } & 36-48 month-old & .74528 & .204 \\
\hline & & 49-60 month-old & -.31581 & .709 \\
\hline \multirow{6}{*}{ Self- Efficacy } & \multirow{2}{*}{ 36-48 month-old } & 49-60 month-old & -1.32076 & $.003 *$ \\
\hline & & $61-72$ month-old & -1.28080 & $.005^{*}$ \\
\hline & \multirow{2}{*}{ 49-60 month-old } & 36-48 month-old & 1.32076 & $.003 *$ \\
\hline & & $61-72$ month-old & .03995 & .999 \\
\hline & \multirow{2}{*}{ 61-72 month-old } & 36-48 month-old & 1.28080 & $.005^{*}$ \\
\hline & & 49-60 month-old & -.03995 & .999 \\
\hline \multirow{6}{*}{ Total Score } & \multirow{2}{*}{ 36-48 month-old } & 49-60 month-old & -2.38185 & $.005^{*}$ \\
\hline & & 61-72 month-old & -2.02609 & $.023 *$ \\
\hline & \multirow{2}{*}{ 49-60 month-old } & 36-48 month-old & 2.38185 & $.005^{*}$ \\
\hline & & $61-72$ month-old & .35577 & .897 \\
\hline & \multirow{2}{*}{ 61-72 month-old } & 36-48 month-old & 2.02609 & $.023 *$ \\
\hline & & 49-60 month-old & -.35577 & .897 \\
\hline
\end{tabular}

The examination of Table 13 shows that the significant difference occurred in "Self-Esteem" subscale of the "DeMoulin Self-Concept Developmental Scale for Children" is between 36-48 month-old and 49-60 month-old children, in favor of 49-60 month-old children. The significant differences occurred in "Self- Efficacy" subscale are found to be between 36-48 month-old and 49-60 month-old children, in favor of 49-60 month-old children; and between 36-48 month-old and 61-72 month-old children, in favor of 61-72 month-old children. Finally, it has been found that the significant differences occurred in "Self-Concept Total Score" are between 36-48 month-old and 49-60 month-old children, in favor of 49-60 month-old children; and between 36-48 month-old and 61-72 month-old children, in favor of 61-72 month-old children.

Table 14. T-Test Results of Children's Self-Concept Average Scores According to Gender

\begin{tabular}{lccccccc}
\hline Subscales & Gender & $\mathrm{N}$ & $\overline{\mathrm{X}}$ & $\mathrm{Sd}$ & $\mathrm{df}$ & $\mathrm{t}$ & $p$ \\
\hline \multirow{2}{*}{ Self-Esteem } & Female & 423 & 35.02 & 4.29 & 808 & -1.026 & .305 \\
& Male & 387 & 35.33 & 4.28 & & & \\
\multirow{2}{*}{ Self- Efficacy } & Female & 423 & 37.13 & 4.06 & 808 & -1.003 & .316 \\
& Male & 387 & 37.41 & 3.81 & & & .268 \\
Total Score & Female & 423 & 72.15 & 7.68 & 808 & -1.109 & .268 \\
& Male & 387 & 72.74 & 7.36 & & & \\
\hline
\end{tabular}

The results presented in Table 14 shows that gender doesn't create a significant difference on the sub-dimensions and total score of the "DeMoulin Self-Concept Developmental Scale for Children" ( $p>.05)$.

\section{Results and Discussion}

Within this study the reliability and validity check of the DeMoulin Self-Concept Developmental Scale for Children, which has been developed by Donald DeMoulin in 1995-1998 and which has been adapted to Turkish by Kuru-Turaşlı (2006) for 6 year-old children was performed for 36-72 month-old children. In addition, self-concept of the children was analyzed according to age and gender variables.

\subsection{Results about Validity and Reliability and Discussion}

In order to determine the reliability and validity of the DeMoulin Self-Concept Developmental Scale for Children, reliability coefficients were calculated through item analysis, test-retest, internal consistency (Cronbach's Alpha) and split-half test methods. In addition, item analysis and $27 \%$ upper-lower comparisons were performed in order to determine item differentiation of the scale. To ensure the validity of the scale, its correlation with "the Social Competence and Behavior Evaluation Scale-30" and "the Emotion Regulation Scale" was checked.

It should be noted that the factor structure of the scale was not analyzed within this study; the original two-factor structure has been kept. Kuru-Turaşlı (2014), explains the two-factor structure as follows: One of two subscales is "self-efficacy" and the other subscale is named as "self-esteem". The "self-efficacy" sucscale is about the child's self-perception of himself or herself as a singular entity, and the "self-esteem" is about the child's perception of himself or herself within a social group. The self-esteem subscale consists of 14, and the self-efficacy subscale consist of 15 items. Becaouse it is a scale adaptation study, the orijinal two-factor structure is accepted and kept.

Item analysis, including item-total, item remainder and item differentiation analysis, have been conducted to check the reliability of the scale. The obtained results were used to examine the additivity of each item and the items with low 
corrected item correlation have been removed from the scale. Since low correlation of an item means that the contribution of this item to the scale is low, it is recommended to remove them from the scale (Kalayc1, 2006). Another important procedure to be applied here is to check the impact of the item that will be removed to the reliability of the scale and deciding accordingly (Coakes, 2005; Özdamar, 2013). As a result of the analysis, it has been found that the lowest item-total correlation is .089 (Item15), whereas the highest correlation is .459 (Item24). It has been concluded that the reliability of the scale will increase if Item15 is removed from the scale. Accordingly, this item whose item-total correlation was below .20, was removed from the scale and a 28-item scale was obtained (DeVon, Block, Moyle, Wright, Ernst, Hayden, Lazzara, Savoy and Kostas, Polston, 2007; Şeker and Gençdoğan, 2014).

The total Cronbach's Alpha value of the scale was found to be .810 , whereas it was .683 for "self-esteem" subscale and .686 for "self-efficacy" subscale. The review of the literature about Cronbach's Alpha, which is the most commonly used tool as the internal consistency coefficient (Cronbach, 1951 cited in Franzen, 2002; DeVon et al., 2007; Drost, 2011), showed that Cronbach's alpha values of .70 and above have been considered to be sufficient (Büyüköztürk, 2002; DeVellis, 2003) according to the standard expressed by Nunnally (1978 cited in Drost, 2011). In addition, Cronbach's alpha values of .80 and above have been considered to be very good in terms of reliability (Kalayc1, 2006; Kline, 2010 cited in Gençtanırım, 2014; Özdamar, 2013). Considering the obtained Cronbach's Alpha value (.810) it can be said that the scale is highly reliable (Şencan, 2005).

The additivity of the items included in a measurement tool should be checked as well. In addition, it has been underlined that the homogeneity of the items contained in the measurement tool, the questions being associated with each other and the structural adequacy of the model are crucial in determining the reliability of the measurement tool (Kalayc1, 2006; Özdamar, 2013). The results of the analysis showed that the items were homogeneous and correlated with each other, also they are additive.

28 items that form the scale were divided into two to obtain half-scales with 14 items and the relationship between these half-scales has been examined (Cohen and Swerdlik, 1998). Pearson correlation coefficient, Spearman-Brown coefficient and Guttman Split-Half coefficient have been analyzed and it has been found that there is a significant relationship between the half-scales. Moreover, the Cronbach Alpha value was found to be .683 for the first half and .685 for the second half. According to Guttman Lambda (Li) method, reliability coefficients were found to very between .781 and .814 , which means that the resulting change in the obtained values was not differentiated much (Coakes, 2005; Gerber and Voelkl, 2005; Kalayc1, 2006; Özdamar, 2013).

Test-retest is one of the mostly used methods to make an assessment about the reliability of the measurement tool over time. Here, the correlation coefficient between two measurement scores performed after a certain time period is evaluated (Cohen and Swerdlik, 1998; Erkuş, 2005; Franzen, 2002; Özgüven, 1999; Rosenthal and Rosnow, 1991 cited in Drost, 2011). The relevant literature sets the appropriate time period for the application of this method as two weeks or one month (Waltz. Strckland and Lenz, 2005 cited in DeVon et al., 2007). Test-retest method was used to statistically test the consistency of the quality measured by the scale in terms of the time. In this context, test-retest results of the scale are as follows: for self-esteem sub-dimension, Pearson correlation coefficient .595, Kendall's tau-b coefficient .433 and Spearman's rho coefficient .562; for self-efficacy sub-dimension, Pearson correlation coefficient .606, Kendall's tau-b coefficient .532 and Spearman's rho coefficient.658; whereas for the total scores, Pearson correlation coefficient .644, Kendall's tau-b coefficient .400 and Spearman's rho coefficient .546. These obtained results were considered to be sufficient to show the reliability of the scale over time (Dede and Yaman, 2008).

In order to determine the validity of the items, the mean scores of upper $27 \%$ and lower $27 \%$ were compared on item basis (Erkuş, 2014). Using item analysis based on the mean scores of upper-lower groups, the differentiation power of the scale (between those who has high self-concept and low self-concept) can be determined. Thus, independent t-tests were performed between the upper $27 \%$ and lower $27 \%$ scores of each item in order to check the differentiation level of the scale's items and it has been found that the differentiation of all items is significant. This result can be interpreted as the scales possess the quality of differentiating children's self-concept (Erkuş, 2005; Büyüköztürk, Çokluk \& Köklü, 2013; Tezbaşaran, 1996).

The Social Competence and Behavior Evaluation Scale-30 and the Emotion Regulation Scale were used to check the criteria validity of the scale. It has been found that "Self-Esteem" and "Self-Efficacy" subscales and total score of the "DeMoulin Self-Concept Developmental Scale for Children" have positive, significant relationships with "Social Competence" subscale of "Social Competence and Behavior Evaluation Scale-30", whereas they have negative significant relationships with "Anger-Aggression" subscale, and they don't have any significant relationship with "Anxiety Withdrawal" subscale.

In addition, it has been found that "Self-Esteem" and "Self-Efficacy" subscales and total score of the "DeMoulin Self-Concept Developmental Scale for Children" have positive, significant relationships with "Emotion Regulation" 
subscale of the "Emotion Regulation Scale", whereas their relationships with "Lability/Negativity" is not significant. With these results, it can be expressed that the "DeMoulin Self-Concept Developmental Scale for Children" fulfills criteria validity (Drost, 2011; Franzen, 2002).

Based on the overall evaluation of obtained results, it has been concluded that the "DeMoulin Self-Concept Developmental Scale for Children" is a valid and reliable measurement tool with this structure. In other words, it can be said that the above mentioned measurement tool can be used to determine self-concept of 36-72 month-old children.

\subsection{Results about Age and Gender Variables and Discussion}

In the very first researches about the development of self-concept in the literature, it has been emphasized that self-concept development cannot be mentioned for children under the age of eight because they haven't reached the required cognitive and developmental level (Harter, 1983). However, the studies conducted with preschool children by the researches as Bates (1990), Damon and Hart (1988), Lewis and Brooks-Gunn (1979) showed that cognitive and language development of the children, which were developing directly proportional with age and which were effective on expressing their self, was at the level to express their self. Similarly, as a result of this research it has been found that children's self-concept is affected by the age variable and self-concept was increased as the age increased. In the review of the relevant literature, Gray-Little and Hafdahl (2000) have examined the self-concept of the children, adolescents and adults from white and black races and they have concluded that the age variable affected self-concept. In addition, Ojo and Akinsola (2012), who evaluated self-concept development of Nigerian, 7-13 year-old children, have found that self-concept has been differentiating according to age and both researches support the findings of this study. Unlike these findings, Barnett and Hunter (2012) and Önder (2004), have concluded that self-concept wasn't differentiating according to age. These differences on the results may have been emerged due to the developmental characteristics of the participating children.

Another result of the study is children's self-concept was not affected by the gender variable. Alawiye and Alawiye (1988), Dündar (2010), İkiz (2009), Jackson, von Eye, Fitzgerald, Zhao and Witt (2010), Kuru-Turaşlı (2006), Mantzicopoulos (2006), Önder (2004), Şeremet (2006), Yakupoğlu (2011) and Zincirkıran (2008) have also concluded that self-concept of preschool children was not differentiating according to gender and these results support the findings of the study. However, in some studies it has been found that self-concept was significantly differentiating according to gender. For instance, Akşin (2013) and Şanlı (2012) found that self-concept of the boys was higher than girls; whereas Bosacki (2007) and Sarica (2010) found that self-concept of the girls was higher than boys. The results obtained in these studies may have been emerged due to the individual characteristics of the participants.

In summary, it has been concluded that the "DeMoulin Self-Concept Developmental Scale for Children" is a valid and reliable measurement tool that can be used to determine self-concept of 36-72 month-old children in Turkey. In addition, it has been found that children's self-concept differentiates according to age and children's positive self-concept increases as the age increases. Moreover, it has been found that 36-72 month-old children's self-concept does not differentiate according to gender.

Based on the results of the research, the following recommendations could be submitted. First of all, researches addressing children of the younger age group, evaluating the effect of different variables such as age, gender, socio-economic status, the duration of pre-school education, education levels of the parents, number of brothers and sisters should be conducted using the "DeMoulin Self-Concept Developmental Scale for Children", whose validity and reliability were proven for 36-72 month-old children. Also, the identification of the children with low and negative self-concept using the "DeMoulin Self-Concept Developmental Scale for Children" and implementing early intervention programs designed for these children may support the development of positive self-concept. Furthermore, the development of self-concept should be monitored from the early childhood to the adolescence using longitudinal studies and the variables that may affect self-concept should be identified.

\section{References}

Akşin, E. (2013). 60-72 aylık çocukların benlik algıları ile ilköğretime hazır bulunuşlukları arasındaki ilişskinin ve ilköğretime hazır bulunuşluk ile benlik algllarının bazı değişkenlere göre incelenmesi [The analysis of the correlation between the self-perception of 60-72 month old children and their school readiness along with the one between school readiness and self-perception in terms of some variables]. Unpublished master's thesis, Marmara University, Educational Sciences Institution, Istanbul, Turkey.

Alawiye, O., \& Alawiye, C. Z. (1988). Self-concept development of Ghanaian school children. The Journal of Psychology, 122(2), 139-145. http://dx.doi.org/10.1080/00223980.1988.9712699.

Arnold, E. C., \& Boggs U. K. (2011). Interpersonal relationships: Professional communication skills for nurses. (pp.159-178). USA-Missouri: Elsevier Health Sciences. 
Barnett, R. A., \& Hunter, M. (2012). Adjustment of siblings of children with mental health problems: behaviour, self-concept, quality of life and family functioning. Journal of Child and Family Studies, 21(2), 262-272. http://dx.doi.org/10.1007/S10826-011-9471-2.

Bates, E. (1990). Language about me and you: Pronominal reference and the emerging concept of self. (Ed. Cicchetti, D. \& Beeghly. M.), The Self in Transition: Infancy to childhood (pp. 165-182). Chicago: University of Chicago Press.

Batum, P., \&Yağmurlu, B. (2007). What counts in externalizing behaviors? The contributions of emotion and behavior regulation. Current Psychology, 25(4), 272-294. http://dx.doi.org/10.1007/BF02915236.

Bosacki, L. S. (2007). Children's understandings of emotions and self: Are there gender differences?. Journal Research in Childhood Education, 22(2), 155-172. http://dx.doi.org/10.1080/02568540709594619

Bouffard, T., Markovits, H., Vezeau, C., Boisvert, M., \& Dumas, C. (1998). The relation between accuracy of self perception and cognitive development. British Journal of Educational Psychology,68(3), 321-330. http://dx.doi.org/10.1111/j.2044-8279.1998.tb01294.x.

Bukato, D., \& Daehler, M. (1992). Child development: A topical approach, U.S.A: Houghton Mifflin Company.

Büyüköztürk, Ş. (2002). Sosyal bilimler için veri analizi el kitabi: İstatistik, araştırma deseni, SPSS uygulamaları ve yorum [Data analysis hand book for social sciences: Statistics, research design, SPSS applications and interpretation]. Ankara: Pegem Akademi Yayıncılık [Pegem Academy Press].

Büyüköztürk, Ş., Çokluk, Ö., \& Köklü, N. (2013). Sosyal bilimler için istatistik. Statistic for social sciences. 13th edition. Ankara: Pegem Akademi Yayınc1lık [Pegem Academy Press].

Coakes, S. J. (2005). SPSS: Analysis without anguish: Version 12.0 for Windows. Australia: John Wiley \& Sons Ins.

Cohen, R. J., \& Swerdlik, M. E. (1998). Psychological testing and assessment: An introduction to tests and measurement (4. Edition). Mountain View, California: Mayfield Publishing Company.

Cugmas, Z. (2002). Preliminary results of the scale of self-perception for school children (SPSC). Early Child Development and Care, 172(1), 35-53. http://dx.doi.org/10.1080/03004430210879.

Çorapçı, F., Aksan, N., Arslan-Yalçın, D., \& Yağmurlu, B. (2010). Okul öncesi dönemde duygusal, davranışsal ve sosyal uyum taraması: Sosyal Yetkinlik ve Davranış Değerlendirme-30 Ölçeği [Emotional, behavioral and social adjustment screening at school entry: Social Competence and Behavior Evaluation-30 Scale]. Çocuk ve Ergen Ruh Sağllğı Dergisi/Turkish Journal of Child and Adolescent Mental Health, 17, 3-14.

Damon, W., \& Hart, D. (1988). Self-understanding in childhood and adolescence. New York: Cambridge University Press.

Dede, Y., \& Yaman, S. (2008). Fen öğrenmeye yönelik motivasyon ölçeği: Geçerlik ve güvenirlik çalışması. A Questionnaire for motivation toward science learning: A validity and reliability study. Necatibey Eğitim Fakültesi Elektronik Fen ve Matematik Ë̆itimi Dergisi/Necatibey Faculty of Education Electronic Science and Mathematics Education, 2(1), 19-37.

DeMoulin, D. F. (2000). I Like Me! Enhancing self concept in kindergarten-age children through active school/business partnerships. NASP Communiqué, 27(8), 141-146.

Demoulin, D. F. (1999). A personalized development of self-concept for beginning readers. Education, 120(1), 14-26.

DeVellis, R. F. (2003). Scale development: Theory and application (Second Edition). Thousand Oaks, CA: Sage.

DeVon, H. A., Block, M. E., Moyle - Wright, P., Ernst, D. M., Hayden, S. J., Lazzara, D. J., Savoy, S. M., \& Kostas Polston, E. (2007). A psychometric toolbox for testing validity and reliability. Journal of Nursing Scholarship, 39(2), 155-164. http://dx.doi.org/10.1111/j.1547-5069.2007.00161.x

Drost, E. A. (2011). Validity and reliability in social science research. Education Research and Perspectives, 38(1), 105-123.

Dündar, B. (2010). Okul öncesi dönem 6 yaş çocuklarının benlik algıları ile bilişsel performansları arasındaki ilişsi [The relationship between the self-perception and the cognitive performance of 6-year-old preschool children]. Unpublished master's thesis, İstanbul University, Social Sciences Institution, Istanbul, Turkey.

Eccles, J. S. (1993). School and family effects on the ontogeny of children's interests, self-perceptions, and activity choices. Nebraska symposium on motivation, 40, 145-208. Lincoln, NE: U. Nebraska Press.

Eccles, J., Wigfield, A., Harold, R. D., \& Blumenfeld, P. (1993). Age and gender differences in children's self - and task $\begin{array}{llll}\text { perceptions during } & \text { elementary } & \text { school. Child } & \text { Development, 64(3), }\end{array}$ 
http://dx.doi.org/10.1111/j.1467-8624.1993.tb02946.x

Erkuş, A. (2005). Bilimsel araştırma sarmalı [Cycle of scientific research]. Ankara: Seçkin Yayınları. Seckin Press.

Erkuş, A. (2014). Psikolojide ölçme ve ölçek geliştirme-I. Temel kavramlar ve işlemler [Assesment and scale development in psychology-1. Basic concepts and transactions] (Second Edition), Ankara: Pegem Akademi Yayınları [Pegem Academy Press].

Franzen, M. D. (2002). Reliability and validity in neuropsychological assessment. 2nd ed. Springer Science \& Business Media. New York: Kluwer Academic/Plenum Publishers.

Gençtanırım, D. (2014). Riskli davranışlar ölçeği üniversite formu: Geçerlik ve güvenirlik çalışmaları [University form of risk behaviors scale: Validity and reliability studies]. Eğitimde ve Psikolojide Ölçme ve Değerlendirme Dergisi/Journal of Measurement and Evaluation in Education and Psychology, 5(1), 24-34.

Gerber, S. B., \& Voelkl, F. K. (2005). Using SPSS for Windows: Data analyses and grahphics. (2nd ed). New York: Springer Science + Bussiness Media, Inc.

Gray-Little, B., \& Hafdahl, A. R. (2000). Factors influencing racial comparisons of self-esteem: a quantitative review. Psychological bulletin, 126(1), 26. http://dx.doi.org/10.1037/0033-2909.126.1.26

Gullo, D. F. (2015). Multiple dimensions of biological development: implications for kindergarten readiness among young children in poverty. Journal of Social Science Studies, 2(1), 106-128. HTTP://DX.DOI.ORG/10.5296/jsss.v2i1.6394

Günalp, A. (2007). Farklı anne baba tutumlarının okul öncesi ĕgitim çağındaki çocukların özgüven duygusunun gelişimine etkisi (Aksaray Ili Örneği), [The effect of the different parents' attitudes on the development of the preschool children's self confidence (Aksaray sample)]. Unpublished Phd thesis, Selcuk University, Social Sciences Institution, Konya, Turkey.

Harter, S. (1983). Developmental perspectives on the self-system. (Ed. Hetherington, E. M. \& Mussen, P. H.), Handbook of Child Psychology: Vol. 4. Socialization, personality, and social development (4th ed., pp. 275-385). New York: Wiley.

Harter, S. (1985). Manual for the self-perception profile for children (revision of the Perceived Competence Scale for Children). Denver, CO: University of Denver Press.

Harter, S. (1999). The construction of the self: A developmental perspective. New York: Guilford Press.

Hattie J. (2014). Self-Concept. USA: Psychology Press.

Huitt, W. (2011). Self and self-views. Educational Psychology Interactive. Valdosta, GA: Valdosta State University.

İkiz, H. (2009). 6 yaş grubundaki çocukların benlik alglları ile aile işlevleri arasındaki ilişkinin incelemesi [The investigation of the relationship between self perception levels of children in 6 years ago group with family functions], Unpublished master's thesis, Marmara University, Educational Sciences Institution, Istanbul, Turkey.

Jackson, L. A., von Eye, A., Fitzgerald, H. E., Zhao, Y., \& Witt, E. A. (2010). Self-concept, self-esteem, gender, race and information technology use. Computers in Human Behavior,26(3), 323-328. http://dx.doi.org/ 10.1016/j.chb.2009.11.001

Kalaycı, Ş. (2006). SPSS Uygulamalı çok değişkenli istatistik teknikleri [Multivaried statictical technics with SPSS applications]. (2. Edition). Ankara: Asil Yayın Dağıtım [Asil Press].

Kapıkıran, N. A. (2004). İdeal ve gerçek benlik kavramı ölçeğinin güvenirliği [Reliability and Validity of ideal and real self-concept scale]. Pamukkale Üniversitesi Ĕ̈itim Fakültesi Dergisi/Pamukkale University Journal of Education, 16(16), 14-25.

Kling, K. C., Hyde, J. S., Showers, C. J., \& Buswell, B. N. (1999). Gender differences in self-esteem: a meta-analysis. Psychological Bulletin, 125(4), 470-500. http://dx.doi.org/10.1037/0033-2909.125.4.470.

Kuru-Turaşlı, N. (2006). 6 yaş grubu çocuklarda benlik algısını desteklemeye yönelik sosyal duygusal hazırlık programının etkililiğinin incelenmesi [Investigate the effect of socia-emotional readiness program to support the self-concept on six years old children's] Unpublished Phd thesis, Marmara University, Educational Sciences Institution, Istanbul, Turkey.

Kuru-Turaşlı, N. (2014). Validity and reliability of the DeMoulin Self-Concept Developmental Scale for Turkish preschoolers. Eurasian Journal of Education Research, 55, 55-72. http://dx.doi.org/ 10.14689/ejer.2014.55.4

LaFreniere, P. J., \& Dumas, J. E. (1996). Social competence and behavior evaluation in children ages 3 to 6 years: The 
short form (SCBE-30).Psychological Assessment, 8(4), 369-377. http://dx.doi.org/10.1037/1040-3590.8.4.369.

Lewis, M., \& Brooks-Gunn, J. (1979). Social cognition and the acquisition of self. New York: Plenum.

Määttä, E., Järvelä, S., \& Perry, N. (2015). Personal and contextual contributors to young children's activity-based perceived self-efficacy. Scandinavian Journal of Educational Research, 1-18. http://dx.doi.org/ 10.1080/00313831.2015.1024161.

Mantzicopoulos, P. (2006). Younger children's changing self-concepts: Boys and girls from preschool through second grade. The Journal of genetic psychology, 167(3), 289-308. HTTP://DX.DOI.ORG/ 10.3200/GNTP.167.3.289-308.

Ojo, A., \& Akinsola, E. (2012). Assessment of self-concept in Nigerian children using an Indigenous Children's Self-Concept Scale. IFE PsychologIA, 20(2), 46-55.

Önder, A. (2004). 4-6 yaşlarındaki okul öncesi çocuklarında kendilik algısının annenin çalışması, yaş ve cinsiyete bağlı olarak incelenmesi [Investigation of self concept of 4-6 aged preschool children according to age, gender and their mothers' working status]. I. Uluslararası Okul Öncesi Eğitim Kongresi. Istanbul: Ya-Pa Yayınları [Ya-Pa Press].

Öner, N. (2009). Türkiye'de kullanılan psikolojik testler: Bir başvuru kaynağı [Psychological Tests used in Turkey: A resource book]. (Second Edition), Istanbul: Boğaziçi Üniversitesi Yayınları [Bogazici University Press].

Özbey, Ç. (2004). Çocuk sorunlarına yapıcı çözümler [Constructive solutions for childhood problems]. İstanbul: İnkılap Yayıncılık [Inkılap Press].

Özdamar, K. (2013). Paket programlar ile istatistiksel veri analizi [Statistical data analysis by packet programs]. (9. Edition). Eskişehir: Nisan Kitapevi [Nisan Press].

Özgüven, İ. E. (1999). Psikolojik testler [Psychological tests]. Ankara: PDREM Yayınları. [PDREM Press].

Pallini, S., Baiocco, R., Schneider, B. H., Madigan, S., \& Atkinson, L. (2014). Early child-parent attachment and peer relations: A meta-analysis of recent research. Journal of Family Psychology, 28(1), 118-123. http://dx.doi.org/10.1037/a0035736.

Preckel, F., Goetz, T., Pekrun, R., \& Kleine, M. (2008). Gender differences in gifted and average-ability students comparing girls' and boys' achievement, self-concept, interest, and motivation in mathematics. Gifted Child Quarterly, 52(2), 146-159. http://dx.doi.org/10.1177/0016986208315834.

Sallay, H. (2000). The role of the family in shaping self-concept and cognitive styles in Hungary. Research Support Scheme Electronic Library, Retrieved July 18, 2015, from http://rss.archives.ceu.hu/archive/00001104/01/94.pdf

Sarıca, Ö. (2010). Okul öncesi eğitim kurumlarına devam eden 5 ve 6 yaş grubu çocuklarının benlik kavramlarının çeşitli sosyo-demografik değişkenlere göre incelenmesi [An examination of 5 and 6 year-old children's self concepts according to various socio-demographic variables], Unpublished master's thesis, Maltepe University, Social Sciences Institution, Istanbul, Turkey.

Shields, A., \& Cicchetti, D. (1997). Emotion regulation among school-age children: the development and validation of a new criterion Q-sort scale. Developmental Psychology, 33(6), $906-916$. http://dx.doi.org/10.1037/0012-1649.33.6.906.

Spilt, J. L., Lier, P. A., Leflot, G., Onghena, P., \& Colpin, H. (2014). Children's social self - concept and internalizing problems: The Influence of peers and teachers. Child Development, 85(3), 1248-1256. http://dx.doi.org/10.1111/cdev.12181.

Şanlı, Z. S. (2012). Probleme dayalı altı aşamalı ders işleme modelinin anaokuluna giden 60-72 aylık çocukların benlik algilarina etkisi. [Effects of the problem-based six-phase lecturing model on the sence of the self perception of 60 to 72 month children]. Unpublished master's thesis, Hacettepe University, Social Sciences Institution, Ankara, Turkey.

Şeker, H., \& Gençdoğan, B. (2014). Psikoloji ve eğitimde ölçme aract geliş̧tirme [Development of assesment tools in psychology and education]. Ankara: Nobel Yayınc1lik [Nobel Press].

Şencan, H. (2005). Sosyal ve davranışsal ölçümlerde güvenilirlik ve geçerlilik [Validity and reliability in social and behavioral measurements]. Ankara: Seçkin Yayıncılık Sanayi ve Ticaret AŞ [Seckin Press].

Şeremet, Ö. E. (2006). Okul öncesi dönemi çocuklarının (5-6 yaş) kendilik algılarının çeşitli değişkenlere göre incelenmesi [Examination of preschooler children (age of 5-6) according to various self-perception], Unpublished master's thesis, Marmara University, Educational Sciences Institution, Istanbul, Turkey.

Tezbaşaran, A. A. (1996). Likert tipi ölçek gelişstirme kılavuzu [Guide to develop Likert type scales]. Ankara: Türk Psikologlar Derneği Yayınları [Turkish Psychologists Association Public]. 
Thompson, A. H., Barnsley, R. H., \& Battle, J. (2004). The relative age effect and the development of self-esteem. Educational Research, 46(3), 313-320. http://dx.doi.org/10.1080/0013188042000277368.

Van den Bergh, B. R., \& Van Ranst, N. (1998). Self-concept in children: Equivalence of measurement and structure across gender and grade of Harter's Self-Perception Profile for Children. Journal of Personality Assessment, 70(3), 564-582. http://dx.doi.org/10.1207/s15327752jpa7003_13.

Verschueren, K., Doumen, S., \& Buyse, E. (2012). Relationships with mother, teacher, and peers: Unique and joint effects on young children's self-concept. Attachment \& Human Development, 14(3), 233-248. http://dx.doi.org/10.1080/14616734.2012.672263

Vervoort, E., Bosmans, G., Doumen, S., Minnis, H., \& Verschueren, K. (2014). Perceptions of self, significant others, and teacher-child relationships in indiscriminately friendly children. Research in Developmental Disabilities, 35(11), 2802-2811. http://dx.doi.org/10.1016/j.ridd.2014.07.004.

Wigfield, A., \& Eccles, J. S. (1992). The development of achievement task values: A theoretical analysis. Developmental review, 12(3), 265-310. http://dx.doi.org/10.1016/0273-2297(92)90011-P.

Wigfield, A., Eccles, J. S., Yoon, K. S., Harold, R. D., Arbreton, A. J., Freedman-Doan, C., \& Blumenfeld, P. C. (1997). Change in children's competence beliefs and subjective task values across the elementary school years: A 3-year study. Journal of Educational Psychology, 89(3), 451. http://dx.doi.org/10.1037/0022-0663.89.3.451.

Wilgenbusch, T., \& Merrell, K. W. (1999). Gender differences in self-concept among children and adolescents: A meta-analysis of multidimensional studies. School Psychology Quarterly, 14(2), 101-120. http://dx.doi.org/10.1037/h0089000.

Yakupoğlu, Y. (2011). Erken çocukluk döneminde yer alan, okulöncesi eğitim kurumuna devam eden çocukların benlik kavramı algısıyla babalarının bağlanma stillerinin (güvenli-korkulu-kayltsız-saplantıll) arasındaki ilişskinin incelenmesi [Investigation of the relationship between fathers's attachment styles (safe, fearful, indifferent, obsessive) and perception of self-concept for children who in early childhood; attendingearly childhood education institutions]. Unpublished master's thesis, Maltepe University, Social Sciences Institution, Istanbul, Turkey.

Zincirkıran Z. (2008). Okul öncesi eğitim kurumlarına devam eden 6 yaş grubu çocuklarının benlik kavramlarının bazı değişkenlere göre incelenmesi [Examination of the self concept of six year old children who attend to preschool education institutions according to different variables]. Unpublished master's thesis, Maltepe University, Social Sciences Institution, Istanbul, Turkey.

This work is licensed under a Creative Commons Attribution 3.0 License. 